\title{
Analysis of selected input data impact on energy demand in office building - case study
}

\author{
Joanna Sinacka ${ }^{1, *}$ and Katarzyna Ratajczak ${ }^{1}$ \\ ${ }^{1}$ Institute of Environmental Engineering, Poznan University of Technology, Berdychowo 4, 60-965 \\ Poznan, Poland
}

\begin{abstract}
In the building designing process special attention should be paid to energy calculations - with analysis of different input data low energy or passive house can be obtained and decision of which parameters can or cannot be changed may be made. The following input data was analysed: shape factor $\mathrm{A} / \mathrm{V}$, glazed area, internal heat gains, air tightness, efficiency of heat recovery. The results show that the input data for the energy calculations are crucial for the obtained result.
\end{abstract}

\section{Introduction}

There are many parameters that need to be taking into account during building designing process. When planning to buy or build a building, an investor expects that the building will be esthetic, comfortable and practical in use, and the operating costs will be low. The primary goal of the designing process must be to meet the national legal requirements that apply to construction projects, but the next step, after fulfilling those requirements, should be to provide climate comfort at the lowest energy consumption, contributing to the low costs of maintaining, which are important to the user.

Energy efficiency of the buildings is regulated by the European Union. All new public buildings in Poland must be nearly zero energy buildings by 31 st of December 2018 and others by 31 st December 2020 [3,5]. In accordance with Polish regulations non-renewable primary energy ratio in new public buildings presently should be lower than $60 \mathrm{kWh} /\left(\mathrm{m}^{2} \cdot \mathrm{a}\right)$ and after 2020 year should decrease to $45 \mathrm{kWh} /\left(\mathrm{m}^{2} \cdot \mathrm{a}\right)$ [7].

The important aspects of energy efficient building designing are its shape and location in relation to the sides of the world. Well thought-out location of the windows, an appropriate selection of their size as well as the shading elements allow to employ a solar radiation (passive heat source) for heating. It is also important to provide the necessary airtightness of the building as well as apply ventilation systems with heat recovery and building materials with good thermal insulation parameters to reduce heat exchange between the internal and external environment.

\footnotetext{
* Corresponding author: joanna.sinacka@put.poznan.pl
} 


\subsection{Passive House Standard}

Passive House concept was defined by Passive House Institute of Darmstadt in Germany in the 1990s [1,2]. Development of Passive House Standard is consequence of the increasing requirements for thermal comfort and indoor air quality. The most important criterion is the energy demand for heating which should not exceed $15 \mathrm{kWh} /\left(\mathrm{m}^{2} \cdot \mathrm{a}\right)$ and the non-renewable primary energy which should be less than $120 \mathrm{kWh} /\left(\mathrm{m}^{2} \cdot \mathrm{a}\right)$ [2].

Passive House Standard (PH) characterise [4]: ensuring thermal transmission (U-value) for external walls below $0,15 \mathrm{~W} /\left(\mathrm{m}^{2} \cdot \mathrm{K}\right)$, no thermal bridges, high air tightness $\left(\leq 0,6 \mathrm{~h}^{-1}\right)$, ensuring high quality windows: low U-value $\left(\leq 0,8 \mathrm{~W} / \mathrm{m}^{2} / \mathrm{K}\right)$ and high total solar energy transmission factor $(\geq 0,5)$, ventilation system with heat recovery efficiency $\geq 75 \%$, limiting heat loss for domestic hot water installation, high efficiency of electricity use, nonrenewable primary energy $(\mathrm{nRPE}) \leq 120 \mathrm{kWh} /\left(\mathrm{m}^{2} \cdot \mathrm{a}\right)$, heating demand $\leq 15 \mathrm{kWh} /\left(\mathrm{m}^{2} \cdot \mathrm{a}\right)$.

\subsection{Polish legal requirements for buildings (Technical Conditions)}

Polish regulations determine the thermal insulation of building envelope, as well as other requirements [7]:

a) Maximum U-values for building envelope by January 01st, 2017 - WT2017 (by December 31st, 2020 - WT2021): $U_{\text {ExternalWall }} \leq 0,23(0,2) \mathrm{W} /\left(\mathrm{m}^{2} \cdot \mathrm{K}\right), \mathrm{U}_{\text {Roof }} \leq 0,18(0,15)$ $\mathrm{W} /\left(\mathrm{m}^{2} \cdot \mathrm{K}\right), \mathrm{U}_{\text {GroundFloor }} \leq 0,3(0,3) \mathrm{W} /\left(\mathrm{m}^{2} \cdot \mathrm{K}\right), \mathrm{U}_{\text {WINDOW }} \leq 1,1(0,9) \mathrm{W} /\left(\mathrm{m}^{2} \cdot \mathrm{K}\right), \mathrm{U}_{\text {ExteriorDoor }}$ $\leq 1,5(1,3) \mathrm{W} /\left(\mathrm{m}^{2} \cdot \mathrm{K}\right)$.

b) The maximum area of glazing - when windows have U-value higher than 0,9 $\mathrm{W} /\left(\mathrm{m}^{2} \cdot \mathrm{K}\right)$, the total area of glazing should be lower than calculated with equation: $\mathrm{A}_{\mathrm{W}, \mathrm{MAX}}=0,15 \cdot \mathrm{A}_{\mathrm{Z}}+0,03 \cdot \mathrm{A}_{\mathrm{W}}$, where $\mathrm{A}_{\mathrm{Z}}$ is area of building plan in $5 \mathrm{~m}$ wide next to external walls and $A_{W}$ is remaining area of building plan in $\mathrm{m}^{2}$.

c) Air flow for each person in office building should be not less than $20 \mathrm{~m}^{3} / \mathrm{h}$.

d) Natural ventilation can be used only if designed minimum air change per hour is not greater than $2 \mathrm{~h}^{-1}$.

e) Air tightness in a building should be no less than $\mathrm{n}_{50}=1,5 \mathrm{~h}^{-1}$ for mechanical ventilation and no less than $\mathrm{n}_{50}=3,0 \mathrm{~h}^{-1}$ for natural ventilation.

f) When air flow is greater than $500 \mathrm{~m}^{3} / \mathrm{h}$, heat recovery system should be applied.

g) The maximum non-renewable primary energy index for heating, ventilation and domestic hot water preparation as well as for cooling and lighting depends on the type of building, and for office buildings from 31st December of 2020, it is respectively: 45 $\mathrm{kWh} /\left(\mathrm{m}^{2} \cdot \mathrm{a}\right), 10 \mathrm{kWh} /\left(\mathrm{m}^{2} \cdot \mathrm{a}\right)$ (for cooling whole building), $50 \mathrm{kWh} /\left(\mathrm{m}^{2} \cdot \mathrm{a}\right)$.

\section{Method}

Analysis was conducted in design PH plug-in to Sketch Up program and in PHPP - passive house planning package, which can be used for designing energy efficient building as well [4]. The following input data were analyzed: shape factor $\mathrm{A} / \mathrm{V}$, glazed area, internal heat gains, air tightness, efficiency of heat recovery. Variants that meet the requirements of Polish technical conditions and requirements for passive buildings have been analyzed.

\section{Building description}

Analysis regards two-storey office building which is intended for 18 employees and its treated floor area is equal $303 \mathrm{~m}^{2}$. Required air stream supply per person is $20 \mathrm{~m}^{3} /(\mathrm{h} p)$, so total supply air is equal $360 \mathrm{~m}^{3} / \mathrm{h}$. Building volume is equal $760 \mathrm{~m}^{3}$ so natural ventilation can be applied. 
Constant input data used in the calculations: the interior temperature: $20^{\circ} \mathrm{C}$ (winter) and $25^{\circ} \mathrm{C}$ (summer), the air stream supply: $360 \mathrm{~m}^{3} / \mathrm{h}$, heat recovery efficiency: $72,7 \%$, the heating and domestic hot water (DHW) source: direct heating (efficiency of heating system: 0,87 ; efficiency of DHW system: 0,55), amount of DHW per person is $6 \mathrm{dm}^{3} /(\mathrm{d} p$ ) (energy demand for DWH $\left.6,4 \mathrm{kWh} /\left(\mathrm{m}^{2} \cdot \mathrm{a}\right)\right)$, the multi-split air conditioning system efficiency of 3,5 .

In basic variants (PH, WT2021) windows area on the south side is equal to $15,33 \mathrm{~m}^{2}$, on the east side $14,58 \mathrm{~m}^{2}$, on the west side $18,0 \mathrm{~m}^{2}$. On the north side windows were not designed. Building envelope for WT2021 and PH (in brackets) is characterise by means of U-value: $U_{\text {ExternalWall }}=0,2(0,1) \mathrm{W} /\left(\mathrm{m}^{2} \cdot \mathrm{K}\right), \mathrm{U}_{\text {Roof }}=0,15(0,1) \mathrm{W} /\left(\mathrm{m}^{2} \cdot \mathrm{K}\right), \mathrm{U}_{\text {GroundFloor }}=0,3(0,12)$ $\mathrm{W} /\left(\mathrm{m}^{2} \cdot \mathrm{K}\right), \mathrm{U}_{\text {WINDOW }}=1,0(0,8) \mathrm{W} /\left(\mathrm{m}^{2} \cdot \mathrm{K}\right), \mathrm{U}_{\text {ExteriorDoor }}=1,3(0,8) \mathrm{W} /\left(\mathrm{m}^{2} \cdot \mathrm{K}\right)$.
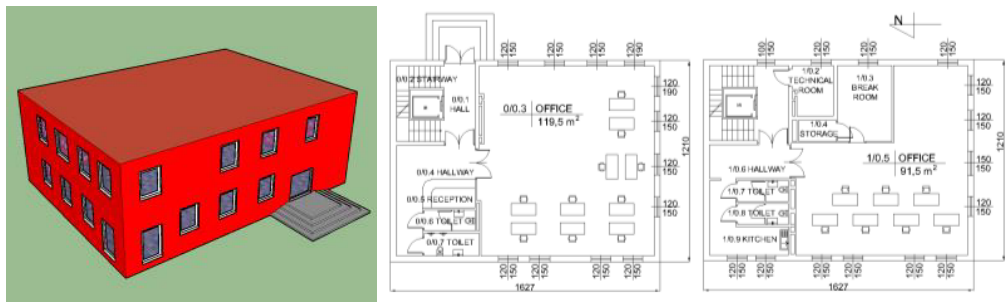

Fig. 1. Building envelope and building plan

\section{Variants}

Seven variants for passive house and building fulfilling Polish Technical Conditions will be analysed. For each variant heating and cooling purposes will be calculated. Comparison of parameters that will be changed in each variant are shown in Table 1.

Table 1. Calculation variants

\begin{tabular}{|c|c|c|c|}
\hline Variant & Comparison of & Changing parameters & Purpose \\
\hline $\begin{array}{c}0 \\
\text { basic }\end{array}$ & ventilation & natural/mechanical & $\begin{array}{l}\text { if natural ventilation is enough to meet the } \\
\text { requirements of the nRPE }\end{array}$ \\
\hline 1 & shape factor & $\mathrm{A} / \mathrm{V}[1 / \mathrm{m}] 0,66 / 0,82 / 0,92$ & impact of building shape \\
\hline 2 & windows area & $\begin{array}{c}\mathrm{Aw}_{w}\left[\mathrm{~m}^{2}\right] \\
25,72 / 51,07 / 134,2 / 175,16\end{array}$ & $\begin{array}{l}\text { if the building meets requirements of } \\
\text { primary energy for heating and cooling }\end{array}$ \\
\hline 3 & orientation & $\begin{array}{l}\text { rotation of building by } \\
0 / 90 / 180 / 270^{\circ}\end{array}$ & $\begin{array}{l}\text { the impact of building orientation on solar } \\
\text { heat gains and consequently energy demand }\end{array}$ \\
\hline 4 & $\begin{array}{l}\text { internal heat } \\
\text { gains }\end{array}$ & $\begin{array}{c}\text { qint }\left[\mathrm{W} / \mathrm{m}^{2}\right] \\
3,5 / 5,7 / 6,2 / 8,8\end{array}$ & $\begin{array}{l}\text { choosing proper values from many } \\
\text { guidelines [6.8] }\end{array}$ \\
\hline 5 & air tightness & $\mathrm{n}_{50}\left[\mathrm{~h}^{-1}\right] 0,6 / 1 / 1,5 / 3$ & impact of air tightness on energy need \\
\hline 6 & $\begin{array}{c}\text { efficiency } \\
\text { of heat recovery }\end{array}$ & $\eta_{\text {HE }}[\%] 50 / 60 / 70 / 80 / 90$ & $\begin{array}{l}\text { impact of efficiency of heat recovery on heat } \\
\text { losses }\end{array}$ \\
\hline
\end{tabular}

\section{Results and discussion}

\subsection{Variant 0 - Basic variant}

Calculations of heating and cooling energy need for the building were made taking into account input data from section 3 . The results are shown on figure 2 . 


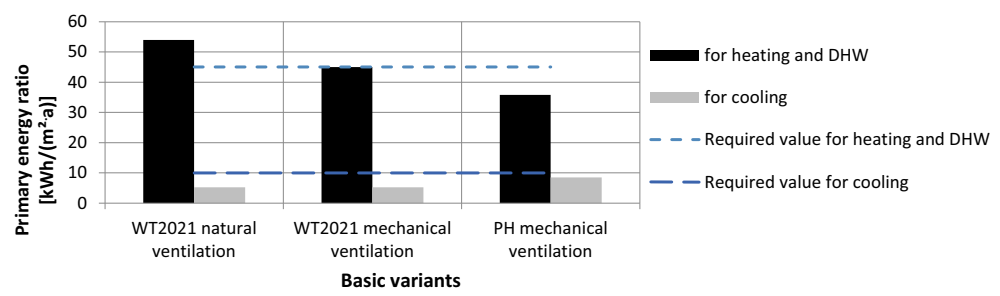

Fig. 2. Basic variants: WT2021 with natural ventilation, WT2021 with mechanical ventilation, PH

Despite applying all data that are required in polish building codes for the year of 2021 non-renewable primary energy criterion is not achieved for building with natural ventilation. Mechanical ventilation with heat exchanger for this building is necessary. This will be basic variant (WT2021) for all other calculations and the other results will relate to it. To show what is the impact of the same input data for passive house all results will relate to passive house $(\mathrm{PH})$ as well.

\subsection{Variant 1 - impact of the building shape factor $A / V$ on energy demand}

The building shape factor $\mathrm{A} / \mathrm{V}$ is defined as a quotient of sum of the external areas of building envelope and the volume of building envelope. The higher $\mathrm{A} / \mathrm{V}$, the higher is the area of surface through which heat flow. Energy efficient buildings must have as low A/V as possible. In calculations three different shapes of the building with the same treated floor area and with windows on the same orientation were compared. The difference is in the area of walls, roof and ground floor. All remaining parameters of the building were unchanged. On figure 3 building shapes are shown. The results of impact of shape factor on energy need for heating and cooling are presented on figure 4.
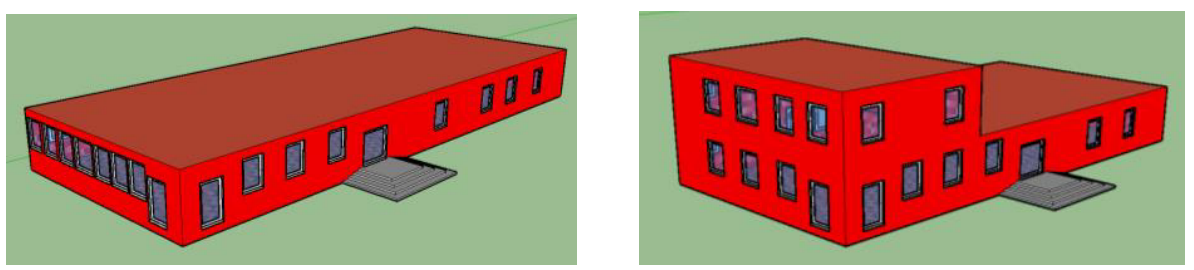

Fig. 3. Building with shape factor of $A / V=0,77 \mathrm{~m}^{-1}$ (left) and $A / V=0,87 \mathrm{~m}^{-1}$ (right)

The shape factor of analysed buildings are for basic variant $\mathrm{A} / \mathrm{V}=0,61 \mathrm{~m}^{-1}$ (two-storey building), 0,77 $\mathrm{m}^{-1}$ for one storey building and $0,87 \mathrm{~m}^{-1}$ for one and a half storey building.

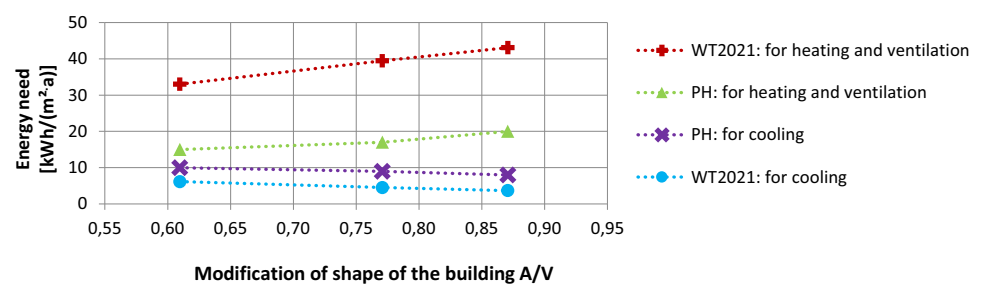

Fig. 4. Impact of the building shape factor $\mathrm{A} / \mathrm{V}$ on heating and cooling energy need

The results show that energy need for heating rises with $\mathrm{A} / \mathrm{V}$ factor. This is due to the increase in surface area through which heat is lost. At the same time energy need for cooling decreases. 


\subsection{Variant 2 - impact of the designed windows area in the building}

On figure 5 results of calculations of non-renewable primary energy for heating and cooling with maximal value are shown. Changing glazed area in the building from 25 to $175 \mathrm{~m}^{2}$ doesn't affect much energy for heating need. Windows have higher heat transfer coefficients, so the building's heat losses are higher, but at the same time more solar heat gains penetrate the building, so heat balance is not changed.
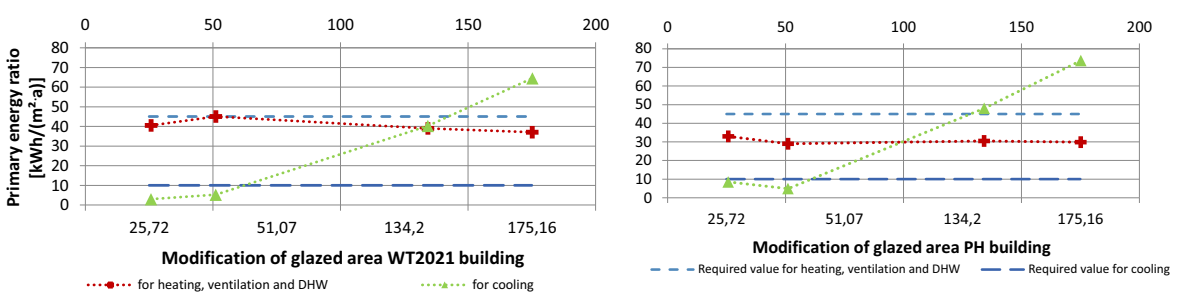

Fig. 5. Impact of glazed area on heating and cooling energy demand

Despite value of energy for heating does not vary much with different glazed area, those areas affects energy for cooling. With increasing glazed area energy for cooling need increases rapidly. Maximum value of non-renewable primary energy ratio for cooling is not exceeded for windows area limited with polish requirement, even when for windows with very low heat transfer coefficient $\left(0,8 \mathrm{~W} /\left(\mathrm{m}^{2} \cdot \mathrm{K}\right)\right.$. When designing buildings with huge glazed area special attention should be paid to shading devices, which can decrease energy need for cooling.

\subsection{Variant 3 - impact of the building orientation}

In the variant 3 the building is rotated up $90^{\circ}, 180^{\circ}$ and $270^{\circ}$. Solar heat gains (SHG) depend on building orientation but they are the same for PH and WT2021: for $+90^{\circ}$ solar heat gains are equal $29,73 \mathrm{kWh} / \mathrm{m}^{2} / \mathrm{a}$, for $+180^{\circ} \mathrm{SHG}=22,25 \mathrm{kWh} / \mathrm{m}^{2} / \mathrm{a}$, for $+270^{\circ}$ $\mathrm{SHG}=32,87 \mathrm{kWh} / \mathrm{m}^{2} / \mathrm{a}$. This analysis show how important is designing a functional layout in such a way that windows on the north side are limited, whereas area of windows on the south side is possibly highest. On the other hand with glazed area on the south side the energy for cooling increases, so designer should find compromise between decreasing energy for heating with no increase of energy for cooling.

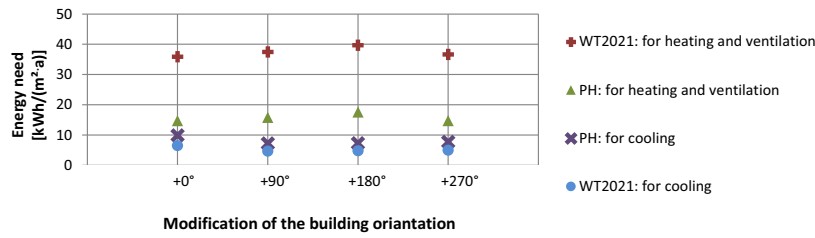

Fig. 6. Impact of building orientation on useable energy

Impact of building orientation on useable energy is presented on figure 6 . The highest heating demand is when building is rotated up $180^{\circ}$ and windows area on north side is the highest. The highest difference is equal to $2,9 \mathrm{kWh} / \mathrm{m}^{2} / \mathrm{a}$ for $\mathrm{PH}$ and $3,8 \mathrm{kWh} / \mathrm{m}^{2} / \mathrm{a}$ for WT2021. 


\subsection{Variant 4 - impact of the internal heat gains}

The amount of internal heat gains that are used in calculations should be carefully selected. Different methodologies for calculating energy demand provide various internal heat gains indicators. Internal heat gains (IHG) have significant influence on energy demand. Each calculated building should be analysed in this respect in great detail and in accordance with its equipment. Incorrect assumptions lead to uncomfortable working conditions. Oversize IHG cause building unheated in winter time, whereas undersize IHG cause an overheating in summer time. Boost $\mathrm{q}_{\text {int }}$ from $3,5 \mathrm{~W} / \mathrm{m}^{2}$ to $8,8 \mathrm{~W} / \mathrm{m}^{2}$ for $\mathrm{PH}$ building causes greater increase in energy demand for cooling than the decrease in heating demand (fig. 7).

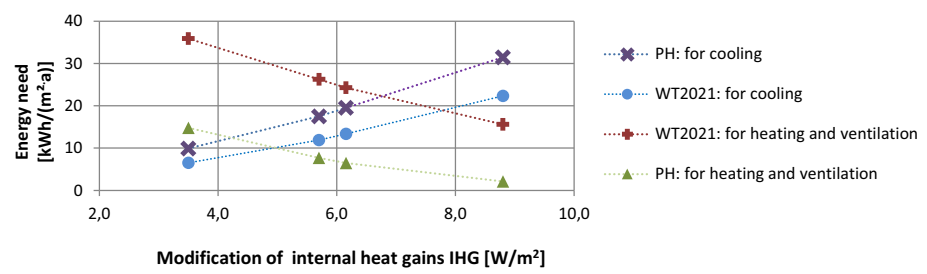

Fig. 7. Impact of internal heat gains (IHG) on energy demand for heating and cooling.

\subsection{Variant 5 - impact of the building air tightness}

In variant 5 ventilation system is analysed. Heat losses rate is equal $\mathrm{H}_{\mathrm{VE}}=22,7 \mathrm{~W} / \mathrm{K}$ for each case, whereas transmission heat losses rate is equal 106,1W/K for $\mathrm{PH}$ and $165,9 \mathrm{~W} / \mathrm{K}$ for WT2021. Heat losses by infiltration depends on air change rate at press. test but is equal for PH and WT2021 (for $\mathrm{n}_{50}=0,6 \mathrm{~h}^{-1} \mathrm{H}_{\mathrm{INF}}=11,5 \mathrm{~W} / \mathrm{K}$ ), for $\mathrm{n}_{50}=1,0 \mathrm{~h}^{-1} \mathrm{H}_{\mathrm{INF}}=19,3 \mathrm{~W} / \mathrm{K}, \mathrm{n}_{50}=1,5 \mathrm{~h}^{-1}$ $\mathrm{H}_{\mathrm{INF}}=29 \mathrm{~W} / \mathrm{K}, \mathrm{n}_{50}=3,0 \mathrm{~h}^{-1} \mathrm{H}_{\mathrm{INF}}=57,8 \mathrm{~W} / \mathrm{K}$.

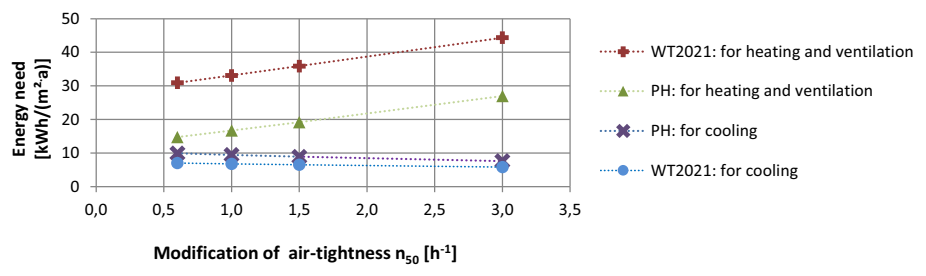

Fig. 8. Impact of air change rate $\left(\mathrm{n}_{50}\right)$ on energy demand for heating and cooling.

When $\mathrm{H}_{\mathrm{inf}} / \mathrm{H}_{\mathrm{ve}}$ ratio increases the importance of mechanical ventilation with heat exchanger decreases and air flow is not under control (for analysed building if $\mathrm{n}_{50}=0,6 \mathrm{~h}^{-1}$ $\mathrm{H}_{\mathrm{inf}} / \mathrm{H}_{\mathrm{ve}}$ ratio is equal $34 \%$ but for $\mathrm{n}_{50}=3,0 \mathrm{~h}^{-1}$ increases to $72 \%$ ). In addition, an increase of $\mathrm{n}_{50}$ about $0.9 \mathrm{~h}^{-1}$ presents heating energy demand an increase about $5 \mathrm{kWh} / \mathrm{m}^{2} / \mathrm{a}$ for WT2021 and about $4,5 \mathrm{kWh} / \mathrm{m}^{2} / \mathrm{a}$ for PH. Cooling energy demand is more stable and for WT2021 decreases about $0,5 \mathrm{kWh} / \mathrm{m}^{2} / \mathrm{a}$ and for $\mathrm{PH}$ decrease about $1 \mathrm{kWh} / \mathrm{m}^{2} / \mathrm{a}$. On the graph (figure 8$)$ the impact of air change rate $\left(\mathrm{n}_{50}\right)$ on energy need for heating and cooling is shown. Ensuring proper (high) air-tightness especially in low energy hand passive houses is very important. 


\subsection{Variant 6 - impact of the effective heat recovery efficiency (ventilation system)}

An effective and economical way to supply a fresh air for buildings is mechanical ventilation with heat recovery. In Variant 6 infiltration heat losses rate are equal 11,5W/K for $\mathrm{PH}$ and $29 \mathrm{~W} / \mathrm{K}$ for WT2021. Heat losses by ventilation system $\mathrm{H}_{\mathrm{vs}}$ for heating depends on effective heat recovery efficiency $\eta_{\mathrm{HR} \text {,eff }}$ and is the same for PH and WT2021. For $\eta_{\mathrm{HR}, \text { eff }}=50 \% \mathrm{H}_{\mathrm{vs}}=41,6 \mathrm{~W} / \mathrm{K}$, for $\eta_{\mathrm{HR}, \text { eff }}=60 \% \mathrm{H}_{\mathrm{vs}}=33,3 \mathrm{~W} / \mathrm{K}$, for $\eta_{\mathrm{HR}, \mathrm{eff}}=65 \% \mathrm{H}_{\mathrm{vs}}=29,1 \mathrm{~W} / \mathrm{K}$, for $\eta_{\mathrm{HR}, \text { eff }}=70 \% \mathrm{H}_{\mathrm{vs}}=25 \mathrm{~W} / \mathrm{K}$, for $\eta_{\mathrm{HR}, \mathrm{eff}}=75 \% \mathrm{H}_{\mathrm{vs}}=20,8 \mathrm{~W} / \mathrm{K}$, for $\eta_{\mathrm{HR}, \text { eff }}=80 \% \mathrm{H}_{\mathrm{vs}}=16,7 \mathrm{~W} / \mathrm{K}$, for $\eta_{\mathrm{HR}, \mathrm{eff}}=85 \% \mathrm{H}_{\mathrm{vs}}=12,5 \mathrm{~W} / \mathrm{K}$, for $\eta_{\mathrm{HR}, \mathrm{eff}}=90 \% \mathrm{H}_{\mathrm{vs}}=8,4 \mathrm{~W} / \mathrm{K}$. In case of cooling (summer time) there is no heat recovery. Mechanical ventilation is realized by bypass.

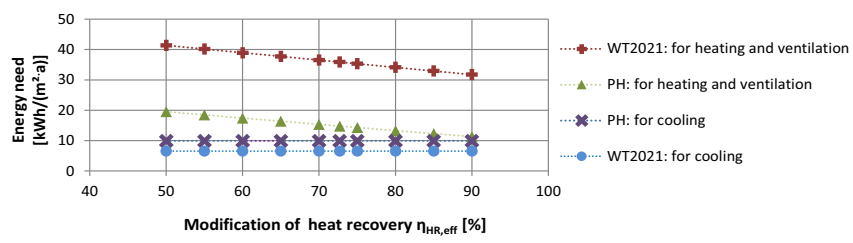

Fig. 9. Useable energy and heat losses by ventilation system versus total ventilation heat losses ratio

Analysis, which results are presented in Fig. 9, confirm the importance of effective heat recovery efficiency for an useable energy. An increase of efficiency $\eta_{\text {HR,eff }}$ leads a decrease energy demand, for example increase of $\eta_{\mathrm{HR} \text {,eff }}$ about $20 \%$ presents heating energy demand a decrease about $4,8 \mathrm{kWh} / \mathrm{m}^{2} / \mathrm{a}$ for WT2021 and about $4,0 \mathrm{kWh} / \mathrm{m}^{2} / \mathrm{a}$ for PH. High efficiency $\eta_{\mathrm{HR}, \text { eff }}$ is necessary for energy-efficient building.

It is important to provide mechanical ventilation with heat recovery, because with no heat recovery it is not possible to meet requirements for non-renewable primary energy and low energy demand for heating, especially, for passive house standard.

\section{Summary}

The results showed that input data for energy calculations are very important, because they can change the final result and they are crucial to meet the requirements of energy standards. Designer can decide what is the most important factor in the design and choose appropriate solution to receive required building parameters. For example, when building has large area of glazing which is characterized by a high heat transfer coefficient and it influences significantly the high usable energy, reducing energy consumption is possible by using other components with better parameters (e.g. mechanical ventilation system with higher heat recovery efficiency). Another example is a building with a complicated shape so its shape factor is far from perfection. In order to reduce energy consumption building materials with a lower thermal conductivity can be used.

Simulations of different variants which take into account various input data can be very helpful in the design process, while knowledge of impact the various input data on the final result allows to choose design variants properly.

When designing a building, the final effect should be considered. Of course, the precedent requirements are those resulting from the legal regulations and standards, however building that meets these requirements may have different levels of energy consumption for heating and cooling. Modeling of energy demand and analysis of the various input data impact on the final result are helpful during decision making process: how a building should look like, what materials and equipment should be applied and what will be the energy consumption - meaning the costs of the building and operation costs. 


\section{References}

1. Ł. Amanowicz, E. Szczechowiak, COW, 48, (2017)

2. V. Badescu, N. Rotar, S. Budea, Sustainable Cities and Society 24, (2016)

3. V. Badescu, N. Rotar, I. Udrea, Energ. Effic. 8, (2015)

4. Directive 2010/31/EU ,Official Journal of the European Union L 153/13

5. W. Feist, PHPP Passive House Planning Package - The energy balance and design tool for efficient buildings and retrofits (Passive House Institute, Darmstadt, Germany, 2015)

6. M. Kassai, , Energy Procedia, 112 ( 2017 )

7. Polish law: Dz.U. poz. 376, (2015)

8. Polish law: Dz.U. poz. 1422, (2015)

9. VDI 2078:2015-06 